\title{
Liberalism(s) and the Critical Securitization of Development Debate
}

\author{
Abstract \\ The securitization of development theme has developed substantially since the late 1990s within the \\ critical global governance literature. To varying degrees contributors to this debate argue that a \\ liberal global governance complex links the discourses of security and development in what is \\ described as the 'security-development nexus', such that the South is conceived as an international \\ security threat. Whilst the security-development nexus itself has been thoroughly explored, the use of \\ the central concept of liberalism has not. This paper addresses this issue through demarcating and \\ critiquing the three readings of liberalism relevant to the securitization of development debate. \\ Identifying and elucidating the three distinct strands of liberalism enables this paper to identify \\ several weaknesses within the debate and propose a number of amendments. This includes \\ proposing that the liberal discourse of global governance reflects complexity rather than consensus \\ and that the centrality of 'liberalism' is at the expense of a robust investigation into how the \\ structural power of global capitalism underpins the security-development nexus.
}

Key Words: Development, Security, Global Governance, Liberalism, Securitization

\section{Introduction}

The securitization of development theme has grown substantially since the late 1990s and is influential within both the critical security (Hettne, 2010) and development fields (Thomas, 2001), and within the increasing body of literature dealing with global governance (Cochrane et al., 2003; Wilkinson, 2005). Indeed much of the securitization of development debate has developed within the critical global governance literature. To varying degrees contributors to this debate argue that a liberal global governance complex links the discourses of security and development in what is described as the 'security-development nexus', such that the South is conceived as an international security threat. Liberal global governance as conceptualised within this debate is a fragmented system of rule, united through a liberal consensus that provides the normative and discursive structure through which its activities are legitimised and coordinated (Dillon and Reid, 2001:45-47; Duffield, 2001a; 2007:8; 2010:57). Economically, this liberal paradigm includes neo-liberal market orientated economics, whilst politically, liberal principles of democratic representation, individual liberty and rule of law are advocated. Liberal global governance, it is argued, is dedicated to obtaining peace and security in the 'borderlands' through transforming these peripheral areas, using 
the Western ideal of contemporary liberal economic and political tenets (Bradbury, 2003; Dillon, 2003; Duffield, 2010:57, 2001a:22).

Authors who systematically develop this claim within the context of a liberal global governance complex include Bradbury (2003), who makes this case with reference to Somalia, and Duffield (2001a, 2001b, 2002, 2004, 2007) and Wilkin (2002), who argue that the synthesis of the two discourses of security and development is a coherent and unifying strand of global governance. Dillon and Reid (2000) also emphasise that in order to achieve a 'liberal peace', international aid agencies are making the delivery of aid conditional upon recipients meeting the good governance criteria. Numerous other authors contribute to this debate (Beall at al., 2005; Thomas 2004; Woods, 2005). Some accounts are more fully developed than others. Whilst some focus primarily on the securitization of development (Wilkin, 2002), others draw on and provide insights into specific aspects of the debate, such as the liberal transformation of communities within developing countries (Young, 1995).

The concept of liberalism, then, is central to the securitization of development debate. And, whilst the security-development nexus itself ${ }^{i}$ has been thoroughly explored (Security Dialogue, 2010 issue $41(1))$, the use of this central concept within the critical academic debate, has not. This paper addresses this issue through demarcating and critiquing the three readings of liberalism relevant to the securitization of development literature: liberalism as a coherent political philosophy; liberalism as a technology of governance; and neoliberalism as governmentality. The demarcation of these different strands is not apparent within the existing debate. Moreover, there are fundamental problems with the first strand of liberalism and a tendency to use at least two of these strands interchangeably, leading to tensions within and omissions from the debate. The centrality of the ideas of liberalism has also come at the expense of a robust investigation into how the structural power of global capitalism underpins the security-development nexus. The paper deals with each of these readings of liberalism in turn before turning to this latter issue.

The first reading, liberalism as a coherent discourse of global governance, is often used by those contributions influenced by neo-Gramscian ideas (Hoogvelt, 2001). Using this interpretation, liberal societal transformation is understood as a response to the security-development nexus (Duffield, 2001a:259): the creation of liberal democratic societies with market economies will engender peace and stability.

In this first reading, discourse is understood as a way of creating, legitimising and reproducing (unstable, contingent and incomplete) hegemonic orders, absorbing alternative meanings and marginalizing resistance. This resonates with Stritzel's idea of 'power in discourse' as 'the sociopolitical resources and power positions of actors, their political struggles and processes of 
authorization ... to create, challenge, change or amend existing meaning structures' (2012: 550). Influenced by neo-Gramscian accounts, discourse is understood as a tool through which global governance actors formulate meaning and disperse ideas.

In line with Foucault, the second reading understands liberalism not as a political philosophy, ideology, coherent set of ideas or institutional structure, but as a form of governing which seeks to limit and restrain the exercise of authority by governing bodies (Dean, 1999, Foucault, 2010).

The third reading is an extension of the second, that is, neoliberalism as governmentality. This is described as liberalism's contemporary form, or advanced liberalism (Hindess, 2004) and highlights the mentality of the market being internalised by individuals.

The second and third readings of liberalism draw upon a post-structuralist position marked by a focus on the constitutive power of discourse, which' constitutes subjectivities and thereby excludes certain ways of thinking and speaking' (Stritzel, 2012: 550-551). Through the construction of knowledge, discourses mobilize rules, codes and procedures to assert a particular understanding' (Dalby, 1988: 416). Importantly, however, the concept of governmentality embodies more than discourse; it is also concerned with techniques of government or 'power in its multifarious practical, technical manifestations' (Larner and Walter, 2004:3).

Identifying and elucidating the three distinct strands of liberalism enables this paper to propose the following. Firstly, contrary to much of the securitization of development literature (as well as the critical global governance literature) the liberal discourse of global governance reflects complexity rather than consensus. Challenges to the orthodox security-development nexus from within global governance networks are not sufficiently engaged with within the academic securitization of development debate. Engaging with these alternatives highlights the possibility of where and how counter- hegemonic (Cox, 2002) ideas may be constructed.

Secondly, the mechanisms of 'ownership' and 'participation' should be understood through liberalism as a technology of governance. Rather than the adoption of these mechanisms being understood as a response to civil society critique, ownership and participation can be understood as micro-level techniques through which global governance networks can govern through freedoms. Delineating these two strands of liberalism also brings to the fore tensions regarding the rationale for societal transformation through development interventions in the South.

Thirdly, the concept of neo-liberalism as governmentality should be applied to the securitydevelopment nexus - specifically the pursuit of liberal societal transformation in the South. Doing so illuminates how the governance of the global South is made acceptable to global governance networks that are essentially liberal. 
Finally, after investigating the three readings of liberalism, the paper argues that the securitization of development is rooted in the structural inequalities created by global capital and therefore, that the current debate would benefit from a more robust investigation of the structural power of global capitalism alongside the well developed focus on the discursive power of global governance networks.

The institutions whose global development policy discourse and programmes are analysed in order to advance the arguments made about liberalism(s) and the critical securitization of development debate are: the UNDP, the EC, the World Bank and the US, UK, Swedish and Danish governments. This selection reflects the key global governance ${ }^{i i}$ actors identified by scholars contributing to the debate and other critical global governance theorists: Western based international institutions along with Western governments are emphasised as being at the core of global governance networks linking conflict and security in the South (Duffield, 2001a:73-74, 99-107; Hoogvelt, 2001:147; Overbeek, 2005:50; Soederberg, 2004). Furthermore, Denmark and Sweden have traditionally been regarded as 'like minded' states set apart in terms of development policy from other countries of the North (Narman, 1999). They are used within the securitization of development literature to demonstrate the current coherence of global development policy (Duffield, 2001:74). These states are also therefore included.

The wider purpose of the paper then is to enable a more powerful critique of the securitydevelopment nexus; one that has greater potential to unpick and understand the 'underlying cartographies of power' (Reid-Henry, 2011:97-98) at work within this increasingly ubiquitous way of understanding North-South relations (see for example Lutterbeck (2014) and Scarpetta (2015) on the current framing of the increase in refugees from North Africa to Europe).

\section{Liberalism as a Coherent Political Philosophy}

Using the first interpretation, the securitization of development debate provides insights into the production of a liberal discourse guiding global governance; international organisations have constructed a broadly convergent and coherent development policy position centred around the primacy of good or democratic governance, including human rights, the rule of law and accountability (Aid Harmonization, 2005; Duffield, 2001:74; United Nations, 2002; United Nations General Assembly, 2000). However, whilst there is broad discursive agreement on the political element of this liberal discourse, there are three areas of tension not sufficiently explored within the securitization of development debate. The first tension involves how the security-development nexus is conceived by institutions of global governance. The second concerns the primacy of neo- 
liberal economic policy and the third, the idea that developing states should be selectively included into aid networks on the basis of their adherence to a liberal framework (Persson and Karlsson, 2003:27). The current debate tends to overemphasise the consensual aspect of global governance, whilst missing the complexity and diversity of 'narratives' that pervade these networks. As a result, potential forces for change within these networks may be missed.

First then, the global development discourse of the United Nations Development Programme (UNDP) and the Swedish International Development Agency (SIDA) contains different ideas and assumptions than those identified by much of the securitization of development debate (Beall et al, 2006; Duffield, 2001a; 2007; Wilkin, 2002; Woods 2005), and represents a distinct alternative or counter-hegemonic force within the global governance of development (Cox, 2002). Whilst there may be competing discourses within the UN and Swedish government ministries respectively, the UNDP and SIDA have not re-conceptualised underdevelopment as an international security threat, but emphasise human rights and human security as worthy development goals in themselves, requiring no further justification (UNDP 1994; 2007; 2010; Persson and Karlson, 2003; Soder, 2005 ${ }^{\text {iii; }}$ Swedish Ministry of Foreign Affairs, 2003; 2010; Ohlsson, 2000). This contrasts with US and Danish development agencies, which maintain that development policy is central to national security strategies, as well as with the UK and EC, who have an established policy discourse linking international security with underdevelopment(USAID, 2004: Danida, 2004). The alternative assumptions and ideas that underpin the UNDP/SIDA approach to the security-development nexus, including prioritising the needs and interests of the poorest and most vulnerable, are not sufficiently identified within the securitization of development debate (Beall et al, 2006; Duffield, 2001a; 2007; Swedish Ministry for Foreign Affairs, 2010; UNDP, 2007:12-13; Wilkin, 2002; Woods 2005).

Recent contributions to the securitization of development debate have begun to explore the possibility of multiple security-development discourses. Hettne distinguishes between the preSeptember $11^{\text {th }} 2001$ development discourse concerned with 'human security' and 'humanitarian intervention', and a post-September $11^{\text {th }}$ discourse prioritising a 'war against terror' or 'pre-emptive intervention' (Hettne, 2010:45). He concludes that the nexus between development and security is not static or one dimensional. The UNDP/Swedish discourse still resonates with this pre-September $11^{\text {th }}$ discourse, whilst the majority of agencies reviewed have moved towards placing development within a 'war against terror' logic.

Secondly, rejection by the UNDP, Sweden and, in some instances, the UK (DFID, 2006; Vandermoortele, 2004) of specific neo-liberal economic prescriptions, implies that, contrary to its presentation within the critical securitization of development debate, neo-liberalism is not a common ideological framework of global governance, but could instead be described as a 'complex 
and hybrid political imaginary, rather than a coherent ideology' (Larner, 2006:205). To envisage a 'liberal consensus' (Duffield, 2001a:27) does not account for or engage with the conflicting dynamics between the agencies of global governance. Whilst there is broad discursive agreement between the global governance institutions examined in this paper that integration into the global economy is required for economic growth, which is essential for poverty reduction, development and thus security, there is tension regarding the pace of integration and the type of economic growth. The World Bank and USAID emphasise the importance of universal economic integration (including opening borders to trade and deregulating domestic markets) (World Bank, 2004; USAID, 2002a), whilst the UNDP and SIDA argue that the pace of integration must be appropriate for each specific economy (Rodrik, 2001; Swedish Ministry for Foreign Affairs, 2003:5; Vandermoortele et al., 2003:1; UNCTAD and UNDP, 2005). And whilst USAID encourages the pursuit of economic growth without qualification, the UNDP, SIDA and the UK specify that growth must decrease inequality (DFID, 2006:47; Persson and Karlsson, 2003:27; USAID, 2002a).

The idea of selectively including (and excluding) states into aid networks on the basis of their adherence to liberal economic and political norms is a further source of disagreement between development agencies. Whilst there is some agreement that development and security depend to a large extent on domestic factors, USAID, Danida and the World Bank strongly argue that substantially more aid should be given to countries with 'sound' political and economic policy records. Aid, they argue, only helps to increase economic growth and foster security in countries with sound economic management and good governance (Collier, 2002; Danida, 2003; USAID, 2002b; World Bank, 1998a). As a result, 15 selected programme countries received $68.2 \%$ of Denmark's bilateral development assistance in 2003 (Danida 2003; 2004).

Conversely, SIDA is unambiguously critical of the selective approach to aid allocation for two reasons: firstly 'good performers' do not always continue to be so and in such circumstances the withdrawal of aid is not conducive to long-term sustainable development; secondly, people are still in need in 'badly performing' states, and should be supported (Soder, 2005) ) $^{\mathrm{iv}}$ The UNDP criticises the accuracy and data supporting selective approaches, and points out that the dimensions measured by this approach cannot be quantified or assessed objectively (Vandermoortele, 2004).

Such divergence may be indicative of the wider tension between the theoretical underpinning of neo-liberal economic globalization and liberal democratisation. The World Bank and USAID prioritise the former, whilst the UNDP, SIDA and to some extent the EC and DFID prioritise the latter (DIFD, 2006; DFID et al, 2005; Commission of the European Communities, 2005). Whilst USAID argue that neo-liberal policies enhance liberal development and thus contribute to global stability, the human security discourse emphasises that this capitalist logic can undermine liberal development. 
The conflicting principles apparent within the global governance of development are not sufficiently represented within the securitization of development debate. In offering a sufficiently different narrative of poverty and security, one which emphasises human rights and human security, the UNDP and SIDA represent important arenas in which to identify, challenge or subvert dominant discourses. The UNDP and Sweden do not hold the power, especially in terms of development resources, of the World Bank or USAID, but they do have some authority. The UNDP has authority as a UN agency, and Sweden, as a traditional 'like-minded' state. Together they may disrupt the dominant discursive understanding of a security-development nexus.

Depicting a liberal consensus bestows a greater coherence and logic to global governance than is evident through this interrogation of the policy discourse (Dillon and Reid, 2002; 2000: Duffield, 2001a: Selby, 2003). In emphasising coherence, the internally contradictory and contested aspects of the discourse are not sufficiently identified. As Jessop and Sum (2006) note, the unity and consensus generated by successful hegemonic projects is always temporary, if not illusory. And, in constructing liberal global governance as a coherent, knowable unit, the debate may inadvertently reconstruct its hegemony (Larner, 2006:209).

On the other hand, acknowledging complexity enables the identification of alternatives and potential forces for change (Larner, 2006:214). As Larner notes, in acknowledging such complexity we stand a better chance of identifying possibilities to advance social justice (ibid:214). Given its concern with human dignity, personal autonomy and meaningful participation in community life (Thomas, 2000), a development discourse based on human security has greater potential for global solidarity and mutuality, than the international security-development narrative.

\section{Liberalism as a Technology of Governance}

Dillon and Reid $(2001 ; 2000)$ and, in later work, Duffield (2007:6) utilise the second interpretation. This refers to liberalism as a technology of government that supports freedom while governing people through the interconnected natural, social and economic processes that sustain life. A defining characteristic of liberalism, writes Duffield, 'is that it takes people and their life and freedom as its essential reference point' (Duffield, 2007:5). This implies Foucault's conception of biopolitics, described as 'the attempt...to rationalize the problems posed to governmental practice by phenomena characteristic of a set of living beings forming a population: health, hygiene, birthrate, life expectancy, race...' (Foucault, 2010:317). 
Whilst the idea of liberalism as a technology of governance is utilised within the securitization of development debate, it is not directly applied to the mechanisms of ownership and participation which are central to contemporary development interventions. Furthermore, liberalism as a coherent political philosophy and liberalism as a technology of governance, whilst utilised in tandem, imply distinct rationales for liberal societal transformation. This brings to the fore a tension within the securitization of development debate.

Liberalism as a technology of governance could be fruitfully applied to further explore the mechanisms of ownership and participation, which are deemed to be the most appropriate processes through which development policies must be constructed and implemented. The ideas of participation and ownership entered the development orthodoxy following the reorientation of development at the World Bank in the late 1990s and are now utilised by key bilateral and multilateral development institutions (UNDP, 2002:15; Danida, 2003:7; DFID, 1997:37; Persson and Jamtin, 2004:5; Stiglitz, 1998; Swedish ministry of Foreign Affairs, 2003:1; Whaites, 2002; Wolfensohn, 1999:1; World Bank, 2000; United Nations, 2002:2). Without national ownership and widespread civic participation, development policy, it is widely agreed, will fail (Cliffe et al., 2003; Council of European Union, 2005:7-8; Danida, 2004:11; DFID et al, 2005:iii; European Commission, 2000:2; OECD, 2004:2; USAID, 2002a:48). The goal of development assistance, it is argued, must therefore be more procedurally democratic and seek to 'generate public awareness and debate' (ibid:48; USAID, 2005a).

The emphasis on responsibility, empowerment, participation and ownership resonates with liberalism as a form of governance directed towards self-reliance and self-realisation and points towards an ethos of government that attempts to govern life through its freedom. For example, the World Bank's Community Driven Development and Community Driven Reconstruction programmes have involved providing communities with untied funds, allowing them to 'identify their needs, decide on projects to address these needs, manage resources and contracts, monitor implementation, and evaluate outcomes' (Cliffe et al., 2003:2; see also World Bank, 2004b).

Prioritising the processes of ownership and participation implies that the inherent rationality of individuals within developing countries will enable them to come to their own understanding of (liberal) development. Dean (1999:155) refers to this type of governance as 'techniques for selfactualisation' and Dillon and Reid's term 'self-orchestration' is also helpful here. They argue that liberal global governance seeks to 'govern without government or at least with diminished reliance on 'rule'... (2001:47). Governing through ownership and participation seeks to establish development whilst avoiding the harsh conditionalities of the Washington consensus period. This resonates with what Harrison (2004) refers to as post-conditionality; states which have 'internalised' 
the good governance agenda. Post-conditionality politics, he argues, is both more interventionist and less starkly coercive.

Foucault's discussion of liberalism and freedom is also instructive. Liberalism, according to Foucault, is an art of government that can only function insofar as a number of freedoms actually exist. It needs freedom, reasons Foucault, and therefore it must produce it. However, 'this very act entails the establishment of limitations, controls, forms of coercion, and obligations relying on threats' (Foucault, 2010:64). This has resonance when discussing the freedoms of ownership and participation in the context of global development which is underpinned by an unequal power relationship between North and South including, the debt regime, ODA and preconceived Northern development models (Brohman, 1995; Dillon, 2003:24).

The mechanisms of ownership and participation limit the extent to which the direct control of populations is required, and rely instead upon what Foucault calls 'governmentality': the way in which one conducts the conduct of individuals, through the freedoms they enjoy (Foucault, 2010:186). Or, to put it another way, power over others is made operable through the freedoms of those over whom it is exercised (Dean, 1999:46). Liberalism as a technology of governance can, then, be directly applied to development intervention, specifically ownership and participation. This concept of liberalism can aid our understanding of how development interventions work and what structures and beliefs make them possible.

Using these two interpretations of liberalism (liberalism as a political discourse and liberalism as governance through freedoms) also brings to the fore a tension within the analysis of liberal societal transformation, apparent within the debate. Liberalism as a coherent political philosophy underpins the concept of a security-development nexus. I.e. societies must be transformed into liberal democracies in order that they do not pose an international security threat. This is not the same as employing liberal techniques of governance as a moral imperative or to solve the liberal problematic of governing too little or too much. Bradbury (2003) and Beall etal (2006) prioritise the former, as does Duffield (2005; 2001a), who subsequently brings the latter into play (Duffield, 2007). Dillon and Reid $(2001 ; 2000)$ prioritise the moral imperative to 'impose the deliriums of liberation on everyone else' (Young, 1995:530), but also imply the security-development nexus as a driver of transformation in some of their work (Dillon and Reid, 2000:120). How these dynamics can be reconciled within a theory of the securitization of development is beyond that scope of this article, but needs further investigation.

\section{Neo-Liberalism as Governmentality}


Foucault's work on neo-liberalism as governmentality ${ }^{v}$ (the third reading of liberalism) is employed by Dillon and Reid (2001) in relation to liberal global governance, but can also aid our understanding of a central tenet of the securitization of development debate - liberal societal transformation. In this regard there are two important questions that neoliberalism as governmentality can shed light upon. Firstly how do global governance networks govern the poorest when they are no longer colonial dependents and secondly, how is the governance of the Global South made acceptable to a global governance network that is essentially liberal?

The concept of governmentality is used to explain the introduction of political economy into the art of government, which is characteristic of the contemporary form of liberal governance (Donzelot, 2008). As well as concerned with the limit and restraint of governmental authority, neoliberalism, in this reading, involves a form of governance that encourages both institutions and individuals to conform to the norms of the market (Larner, 2006; Larner and Walters, 2004). This is an expansion or development of 'liberalism' broadly understood as concerning either the relationship between a state and its subjects or with the defence of individual liberty and private property. Foucault analyses the development of neo-liberal thought in America and Germany in the second half of the last century. He argues that, according to this school of thought, because the market works most efficiently in conditions of inequality and competition, government must ensure these conditions exist by acting upon the population (Foucault, 2010:119-120). The role of the state is to intervene in favour of the market (rather than because of the market) in such a way that the market and the principle of equal inequality is maintained (Donzelot, 2008:124). This necessity of competition makes individuals into entrepreneurs: 'someone who situates himself in a game and applies himself to increasing his successful outcomes' (ibid:130). In this regard one can establish a conduct of conduct because individuals enjoy autonomy as entrepreneurs of their own life and, as such, are made responsible for it (ibid:130).

Rather than a response to capitalist crisis, neo-liberalism can be understood as a response to the problem of how to govern the world when the poorest are no longer dependents or subjects but citizens of formally independent states (Larner, 2004:9). Direct territorial control is no longer acceptable, therefore political rule needs to be relocated within the market. As such, market interaction is perceived as a powerful instrument of civilisation, inculcating such virtues as prudence, diligence, punctuality and self control. With regard to Southern populations, this view suggests that 
... if only suitable property can be set securely in place and non-market forms of economic activity reduced to a minimum, then market interaction itself may function as a means of improving the character of less civilised peoples (Hindess, 2004:26).

Rose links this to 'advanced liberal rule' that seeks to detach the authority of expertise from the apparatuses of political rule, and relocate experts within a market governed by the rationalities of competition, accountability and consumer demand (Rose, 1993; 285). This can be linked to the production of freedom. People are encouraged to see themselves as individualised and active subjects, responsible for enhancing their own wellbeing. Such individuals are governable, argues Foucault, because they govern themselves according to economic laws and 'one can act on the environment in such a way as to modify ... conduct' (Foucault, 2010: 186). This enables individuals to be shaped and guided whilst at the same time respecting their autonomy (Rose, 1993:290).

Neo-liberalism as governmentality is therefore a fruitful way to analyse liberal societal transformation. The way in which individuals within developing societies are encouraged to be entrepreneurs of their own lives through the processes of ownership, participation and empowerment, and the drive towards competition, anti-corruption, meritocracy and autonomy may be understood as such. Governance of the poorest is through market interaction, rather than political control: through internalising the mentality of market, individuals discipline themselves.

Whilst we may perceive a liberal global governance complex, non-liberal mechanisms are also central to development intervention and implicated in what may be conceived as liberal interventions. For example, selectively including states into aid networks on the basis of their adherence to a good governance agenda is non-liberal in its use of material power to force liberal change: aid networks are using the threat of a withdrawal of aid to induce governments to become more liberal. Liberalism needs to distinguish between what or who can be governed through the promotion of liberty and what must be governed in other ways (Hindess, 2004:20).

In a departure from Foucault, Hindess (2004) offers an explanation of how non-liberal mechanisms of government are intrinsic to liberalism. This is useful when considering the securitydevelopment nexus and Duffield's idea of a developmental trusteeship. Hindess argues that liberalism will always have to deal with individuals and areas of conduct which seem not to be governable through available techniques of government through freedom (ibid:28). Liberalism will need to distinguish between what can be governed through the promotion of liberty and what must be governed in other ways (ibid:30). Hindess argues that liberalism has always made use of illiberal methods of government. In line with Foucault, he highlights the market (free-market, private property) as the arena in which excessive government can be identified. But developing Foucault's 
observations, Hindess maintains that the image of the market also provides a test of who can be governed liberally, and who cannot. Those who do not internalise market principles or the culture of the entrepreneur cannot be governed through freedoms. Those populations who have failed to internalise market principles and govern themselves, need to be governed through coercion and threat. Employing the concept of neo-liberalism as governmentality sheds light on how a liberal global governance network, identified within the securitization of development literature, can delimit a zone of liberal exception.

\section{Combining Structural and Productive Power}

De Goede (2006:1) argues that a post-structural conceptualisation of power, as evident within the critical securitization of development debate, need not disable a critique of capitalism. However, significant contributions to the securitization of development debate (typically those which take inspiration from Foucault, rather than Gramsci) have less to say about the structural power of global capitalism, than the productive power of the networks of liberal global governance (Barnett and Duvall, 2005; Dillon and Reid, 2001; 2000; Duffield, 2007; 2001a). Whilst the idea that the structure of global capitalism generates unequal social privileges is implicit in some of this debate, it does not constitute a subject of robust investigation. This contrasts with other critical scholars contributing to the broader global governance literature (Castells, 1998; Harvey, 2003; Hoogvelt, 2001; Soederberg, 2002).

The structural power of capitalism is important in the work of Clapham, for example, who emphasises that revenues accrued to African states are sustained by exports based on primary products, which are subject to high fluctuations in export prices and affected by a long-term decline in prices (Clapham, 2003:56). And Gill, in demonstrating the structural power of capital, argues that because the process of economic growth depends on the need to maintain investor confidence, governments are driven to sustain their credibility in the eyes of investors by attempting to provide an appropriate business climate (Gill, 2005:176).

In allocating differential capacities and advantages, these structures, to a degree, also determine who can be governed and who is authorised and has the capacity to govern. Global capitalism is therefore implied in the emergence, evolution and definition of systems of global governance. It is through the structures of global capitalism that global governance institutions, in part, derive power. Furthermore, Hoogvelt emphasises that the structure of global capitalism shapes ideology (Hoogvelt, 2001:149). At the same time, by emphasising the responsibility and commitment that must come from developing societies themselves, the liberal development discourse masks the 
structural imperatives which generate inequality. The division between structural and productive forms of power is not therefore clear-cut, and they overlap in important ways (Barnett and Duvall, 2005). Barnett and Duvall highlight that both forms of power concern how the social capacities of actors are socially produced, and how these processes shape actors' understandings and perceived interests (ibid:20). However, whilst they are intimately linked and simultaneously employed within global governance networks, key contributions to the securitization of development debate privilege the productive power of discourse, over the structural constraints of global capitalism (Dillon and Reid, 2001; 2000; Duffield, 2007; 2001a; Young 1995).

Jessop and Sum (2006) attempt to develop an approach to International Political Economy which combines the insights of Gramsci and Foucault (also see Joseph (2011)). They suggest an approach which 'stresses the contradictory and conflictual dynamic of capitalist social formations based on the reciprocal interweaving and interaction of the material and the discursive' (Jessop and Sum, 2006:166). These authors recognise that the structural dynamics of capital accumulation on a world scale and the processes and mechanisms through which political, intellectual and moral leadership is secured have a conjoint impact on capacities for action and transformation.

This approach is instructive in attempting to combine structural power (privileged by neoGramscian accounts) and productive power (privileged by Foucauldian accounts) to construct a theory of the securitization of development. This would entail relating the disciplinary aspects of development policy, including the discourse of ownership, participation and human security, with the dynamics of accumulation on a world scale. But the securitization of development is not only a discursive construct. There are underlying material structural dynamics to this phenomenon. Ontologically, this clearly means, in opposition to positivism and some poststructuralisms, acknowledging that there is a reality independent of our thought about it or our experience of it (Archer, 1998).

Foucault's focus on the micro-level techniques of government is instructive in understanding the micro-level techniques of governance utilised in development interventions. For example, through education and training, Security Sector Reform programmes seek 'cultural' and mindset' change in the judiciary and security sector (Aboagye and Bah, 2004; DFID Caribbean, 2000; World Bank, 2006), whilst, local level development programmes seek to change the attitudes, perceptions, values and behaviour of communities (McNeil and Woolcock, 2005:3). Theorising liberal societal transformation through the lens of Foucault's concept of liberalism as a technology of governance could also potentially highlight the agency of local actors in self-regulating their conduct (Foucault, 2010). From this perspective, domestic actors have internalised the conceptions of a 'free' liberal self, demonstrating the possibility of limited self government (Dean 1999; Harrison, 2004). 
A Foucauldian approach, however, has less to say about how global governance networks are able to implement such intrusive projects - the strategic relationships of power that these projects imply (Dean, 1000:47). Socio-economic relations of dominance and strategy are often apparent in development policies. These material dynamics are crucial in theorising the unequal power relations that exist in relation to global governance networks and the Global South. As Harrison (2004:4) observes, the World Bank is able to produce 'governance states' in large part through its ability to dispense hard currency. Structural power relations are implicit when we consider the securitydevelopment nexus, which involves global governance networks utilising development policy and aid in the interests of wider stability (Danida, 2003; USAID, 2002a).

Thus an approach rooted in Gramsci, which grounds the exercise of power in specific material apparatuses and specific social practices, and asks how order is secured, would be instructive (Jessop and Sum, 2006:164). An approach which appreciated the reciprocal relations between the political, economic and ideological fields would highlight the way in which dominance and social power are enacted through the discourses of the security-development nexus and liberal democratic development. It would also include an analysis of the emergent structural properties that underlie power relations. A more explicit analysis of this would systematically investigate the effects of, for example, accumulation by dispossession, spatio-temporal fixes and other socio-economic practices on Southern populations (Harvey, 2003). These may include forms of exclusion, the creation of 'surplus populations', increased parallel economic activity and non-liberal development. These dynamics are discursively identified by global governance as threats to wider security (the securitydevelopment nexus), but are also of course embedded within wider social, historical and material relations (see for example, Soederberg, 2004).

\section{Conclusion}

Through demarcating the multiple meanings of liberalism salient to the securitization of development debate, this article has proposed a number of additions and amendments to move the debate forward. Understanding liberalism as a coherent philosophy, as do a number of contributions to the debate, draws attention to the liberal political discourse of global governance. However, depicting global governance as unified through a liberal consensus endows a greater coherence to these discourses than they warrant. In doing so, internal contradiction, contestation and contingency is obscured. An approach to these related discourses which makes visible the 'messy actualities' (Larner, 2006) of global governance may reveal potential and spaces for specific 
emancipatory change. This would include acknowledging the different narratives linking security and development, which would engender a more robust understanding of this discourse.

Utilising the idea of liberalism as a technology of governance gives insight into how development involves the production of freedom and entails limitations and coercion. It highlights liberal societal transformation as a key rationale of global governance and offers a salient theoretical tool for understanding 'ownership' and 'participation' within the global development agenda. However there is a need to establish greater clarity regarding the drivers of liberal societal transformation in the South and deeper engagement with the wider literature concerned with liberal societal transformation (Harrison, 2004)

Applying neoliberalism as governmentality to the debate sheds light upon how the non-liberal practices of development intervention become acceptable to a global governance network that is essentially liberal.

Finally, a theory of the securitization of development needs to pay greater attention to the structural dynamics of the global economy, including how these are linked to the production of discourse. The (important) focus on liberalism(s) as a coherent philosophy or technique of power, should not exclude an analysis of the underlying structures of global capital accumulation that perpetuate the very global inequalities that are currently framed as security issues by global governance networks.

The security-development nexus reinforces the delinking of development assistance from the principle of solidarity and the redistribution of wealth. Instead, development interventions are understood as a tool of Western security. It is this that the securitization of development debate is seeking to critique. In delineating the three strands of liberalism this paper contributes to the debate by providing greater clarity and further tools through which to reveal the 'underlying cartographies of power' that inform the nexus. Furthermore, in demonstrating that complexity rather than coherence characterises networks of global governance, it also has implications for critical global governance studies that lean towards conceptualising global governance as a knowable, coherent unit.

Aboagye, F. B. and Bah, A. M. S. (2004) Liberia at a Crossroads: a preliminary look at the United Nations Mission in Liberia (UNMIL) and the Protection of Civilians, Institute for Security Studies, Pretoria, South Africa. Available from: http://www.apstaafrica.org/pdf/paper95.pdf

Aid Harmonization (2005) Paris Declaration on Aid Effectiveness: ownership, harmonisation, alignment, results and mutual accountability, High-Level Forum, 2 March, Paris. Available from: http://www.oecd.org/dataoecd/11/41/34428351.pdf 
Annan K A (2006) Governance for the Future: democracy and development in the Least Developed Countries. In Hoover, J. (ed.) Governance for the Future. Democracy and Development in the Least Developed Countries, New York, UNDP and UN-OHRLLS, p. 1.

Archer M. (1998) Introduction: Realism in the Social Sciences. In: Archer, M et al. (eds.) Critical Realism: Essential Readings, London and New York, Routledge, pp. 189-205

Barnett and Duvall (2005) Power in Global Governance. In: Barnett and Duvall (eds.) Power in Global Governance, Cambridge, Cambridge University Press, pp. 1-31.

Beall J, Goodfellow T, and Putzel J (2005) 'Introductory Article: On the Discourse of Terrorism, Security and Development' Journal of International Development, 18 (1), 5-67

Bell, L (2003) The Global Conflict Prevention Pool, London, MOD.

Bradbury M (2003) 'Living with statelessness: the Somali road to development', Conflict, Security and Development, 3, 8-25.

Brohman J (1995) 'Universalism, Eurocentrism, and ideological bias in development studies: from modernisation to neo-liberalism', Third World Quarterly, 16 (1), 121 162.

Castells M (1998) End of Millennium, Oxford, Blackwell Publishers.

Clapham C (2003) Global Governance and State Collapse. In: Cochrane, F, Duffy, R and Selby, J (eds.) Global Governance, Conflict and Resistance, Hampshire UK, Palgrave MacMillan.

Cliffe S, Guggenheim S and Kostner M (2003) Community-Driven Reconstruction as an Instrument in War-to-Peace Transitions, Washington DC, World Bank.

Cochrane F, Duffy R and Selby J (2003) Global Governance, Conflict and Resistance, Hampshire UK, Palgrave Macmillan.

Collier P (2002) Making Aid Smart: institutional incentives facing donor organisations and their implications for aid effectiveness, USAID

Commission of the European Communities (2005) Proposal for a Joint Declaration by the Council, the European Parliament and the Commission on European Union Development Policy. Brussels, European Commission

Council of the European Union (2005) The European Consensus on Development, Brussels, European Commission. Available from:

http://ec.europa.eu/development/icenter/repository/european_consensus_2005_en. pdf

Cox, R and Schechter, M G. The Political Economy of a Plural World: Critical Reflections on Power, Morals and Civilization, Sussex UK, Psychology Press.

Danida (2003) A World of Difference, The Governments Vision for New Priorities in Danish Development Assistance 2004-2008, Copenhagen, Royal Danish Ministry of Foreign Affairs.

Danida (2004) Security, Growth - Development, Copenhagen, Royal Danish Ministry of Foreign Affairs.

Dean M (1999) Governmentality: Power and Rule in Modern Society, London, Sage.

DFID (1997) Eliminating World Poverty: a challenge for the 21 st century. White Paper on International Development, London, The Stationary Office Limited. 
DFID (2006) Eliminating World Poverty: making governance work for the poor. A White Paper on International Development, London, The Stationary Office Limited.

DFID Caribbean (2000) Project Memorandum: Jamaica Constabulary Reform and Modernisation Project, London, DFID.

DFID, FCO and HM Treasury (2005) Partnerships for Poverty Reduction: rethinking conditionality, London, DFID, FCO, HM Treasury. Available from: http://www2.ohchr.org/english/issues/development/docs/conditionality.pdf

Dillon M (2003) Global Liberal Governance: networks, resistance and war. In: Cochrane, F. (ed.) Global Governance, Conflict and Resistance, Basingstoke, Palgrave Macmillan, pp. $21-40$.

Dillon M and Reid J (2000) 'Global Governance, Liberal Peace, and Complex Emergency', Alternatives, 25, 117-143.

Dillon M and Reid J (2001) 'Global Liberal Governance: bio-politics, security and war' Millennium: Journal of International Studies, 30, 41-66.

Donzelot J (2008) 'Michel Foucault and liberal intelligence', Economy and Society, 37 (1), 115-134.

Duffield M (2001a) Global Governance and the New Wars: the merging of development and security, London, Zed Books Ltd.

Duffield M (2001 b) 'Governing the Borderlands: decoding the power of aid', Disasters, 25, 308-320.

Duffield M (2002) 'Social Reconstruction and the Radicalization of Development: aid as a relation of global liberal governance', Development and Change, 33, 1049-1071.

Duffield M (2004) Human Security: reinstating the state, unpublished.

Duffield M (2007) Development, Security and Unending War. Governing the World of Peoples, Cambridge, Polity Press.

Duffield M (2008) Global Civil War: The Non-Insured, International Containment and PostInterventionary Societ', Journal of Refugee Studies, 21 (2), 145-165.

Duffield M (2010) 'The Liberal Way of Development and the Development-Security Impasse: Exploring the Global Life-Chance Divide', Security Dialogue, 41, 53-76.

European Commission (2000) The European Community's Development Policy - Statement by the Council and the Commission, Brussels, European Commission.

Foucault M (2010) The Birth of Biopolitics. Lectures at the College De France 1978-1979. Eds: Senellart, M, Ewald, F, Fontana, A. Trans: Burchell, G. Hampshire Palgrave Macmillan.

Gill S (2005) New Constitutionalism. In: Wilkinson, R. (ed.) The Global Governance Reader, London, Routledge, pp 174-186.

Goede M (2006) Introduction: International Political Economy and the Promises of PostStructuralism. In: Goede, M (ed.) International Political Economy and Post-Structural Politics, Hampshire, Palgrave Macmillan, pp. 1-20.

Harrison G (2004) The World Bank and Africa: The Construction of Governance States, London, Routledge.

Harvey D (2003) The New Imperialism, New York, Oxford University Press. 
Hettne B (2010) 'Development and Security: Origins and Future', Security Dialogue, 41 (1), 31-52.

Hindess B (2004) Liberalism - what's in a name? In: Larner, W. and Walters, W. (eds.) Global Governmentality: Governing International Spaces, London, Routledge, pp. 21-39

Hoogvelt A (2001) Globalization and the Postcolonial World: the new political economy of development, Basingstoke, Palgrave.

Jessop B and Sum N (2006) Towards a Cultural Political Economy: Poststructuralism and the Italian School. In: Goede M (ed.) International Political Economy and Post-Structural Politics, Hampshire, Palgrave Macmillan, pp. 157-176.

Joseph J (2011) 'How should we make the case for Critical Terrorism Studies? Ontology, social relations and historical materialism' Unpublished

Larner W (2006) Neoliberalism: Policy, Ideology, Governmentality. In: Goede M (ed.) International Political Economy and Post-Structural Politics, Hampshire, Palgrave Macmillan, pp. 199-218.

Larner W and Walters W (2004) Introduction: global governmentality. In: Larner W and Walters W (eds.) Global Governmentality: Governing International Spaces, London, Routledge, pp. 1-20

Lutterbeck, D (2006) Policing Migration in the Mediterranean, Mediterranean Politics, 11 (1), 59-82

McNeil, M. and Woolcock, M. (2005) A New Framework for Social Development: the case of Kecamatan, Washington DC, World Bank.

OECD (2004) Security System Reform and Governance: policy and good practice, Paris, OECD. Available from: http://www.oecd.org/dataoecd/20/47/31642508.pdf

OECD (2007) Principles for Good International Engagement in Fragile States, Paris, OECD. Available from: http://www.oecd.org/dataoecd/61/45/38368714.pdf

Ohlsson L (2000) Livelihood Conflicts: linking poverty and environment as causes of conflict, Stockholm, SIDA. Available from:

http://waterwiki.net/images/6/68/Livelihood_conflicts_linking_poverty_and_environ ment_as_causes_of_conflict.pdf.

Pender J (2001) 'From 'Structural Adjustment' to 'Comprehensive Development Framework': conditionality transformed?' Third World Quarterly, 22, 397-411.

Persson G and Jamtin C (2004) Sweden's Global Development Policy, Stockholm, Ministry of Foreign Affairs.

Persson G and Karlsson J. O (2003) Shared Responsibility: Sweden's policy for global development, Government Bill 2002/3:122, Stockholm Swedish Ministry for Foreign Affairs.

Porter D and Craig D (2004) 'The third way and the third world: poverty reduction and social inclusion in the rise of 'inclusive' liberalism' Review of Political Economy, 11 (2), 387-432.

Reid-Henry S (2011) 'Spaces of Security and Development: An alternative mapping of the security', Security Dialogue, 42 (97), 97-104.

Rodrik D (2001) The Global Governance of Trade; as if development really mattered, New York, UNDP. 
Rose N (1993) ' Government, authority and expertise in advanced liberalism', Economy and Society, 22 (3), 283-299.

Ronenau, J. (2002) Governance in a New Global Order. In Held, D and McGrew, A. (eds). Governing Globalization: Power, Authority and Global Governance. Cambridge, Polity Press, pp70-86.

Scarpetta, V (2015) The Mediterranean Migrant Crisis: What can be done? Open Europe [Blog Post] Retrieved from www.openeurope.org.uk/blog/the-mediterraneamigration-crisis

Selby J (2003) Introduction. In: Cochrane, F, Duffy, R, Selby, J (eds.) Global Governance, Conflict and Resistance, Hampshire, UK, Palgrave Macmillan, pp. 1-18.

Soederberg S (2002) 'On the Contradiction of the New International Financial Architecture: Another procrustean bed for emerging markets?', Third World Quarterly, 23 (4), 607-620.

Soederberg S (2004) 'American empire and 'excluded states': the Millennium Challenge Account and the shift to pre-emptive development', Third World Quarterly, 25 (2), 279-302.

Stern M and Öjendal J (2010) 'Mapping the Security--Development Nexus: Conflict, Complexity, Cacophony, Convergence?' Security Dialogue, 41, 5-29.

Stiglitz J (1998) Towards a New Paradigm for Development: strategies, policies, and processes, Prebisch Lecture at UNCTAD, 19 October, Geneva.

Swedish Ministry for Foreign Affairs (2003) Sweden's New Policy for Global Development, Stockholm Swedish Ministry for Foreign Affairs. http://www.oecd.org/dataoecd/24/6/31675045.pdf

Swedish Ministry for Foreign Affairs (2010) Change for freedom: Policy for democratic development and human rights in Swedish development cooperation, 2010-2014 Available from: http://www.sweden.gov.se/content/1/c6/14/32/33/14dceded.pdf

Thomas C (2001) 'Global Governance, Development and Human Security: exploring the links', Third World Quarterly, 22, 159-175.

Thomas C (2004) International Organisations, Development Strategy and the Challenge Ahead, Unpublished.

UNCTAD and UNDP (2005) Competitiveness and Social Efficiency, New York, UN. Available from: http://www.globalprogramme.com/news/article.php3?id_article=155

UNDP (1994) Human Development Report 1994: new dimensions of human security, Oxford, Oxford University Press.

UNDP (2002) Justice and Security Sector Reform, BCPRs Programmatic Approach, New York, UNDP. Available from:

http://pksoi.army.mil/doctrine_concepts/documents/UN/jssrprogramaticapproach.p $\mathrm{df}$

UNDP (2007) Making Globalisation Work for All: United Nations Development Programme Annual Report 2007, New York, UNDP. Available from: http://www.undp.org/publications/annualreport2007/IAR07-ENG.pdf. 
UNDP (2010) Human Development Report 2010 - 20th Anniversary Edition. The Real Wealth of Nations: Pathways to Human Development, New York, UNDP. Available from: http://hdr.undp.org/en/reports/global/hdr2010/chapters/

United Nations (2002) Report of the International Conference on Financing for Development, Monterrey, Mexico, UN.

United Nations (2005) UN Millennium Development Goals, Washington DC, UN. Available from: http://www.un.org/millenniumgoals/

United Nations General Assembly (2000) Resolution adopted by the General Assembly, 55/2. United Nations Millennium Declaration, New York, United Nations.

USAID (2002a) Foreign Aid in the National Interest: promoting freedom, security and opportunity, Washington DC, USAID. Available from:

http://www.rmportal.net/library/content/higherlevel_fani/view

USAID (2002b) Millennium Challenge Account Update, USAID. Available from: http://www.usaid.gov/press/releases/2002/fs_mca.html

USAID (2004) U.S Foreign Aid: meeting the challenge of the twenty-first century, Washington DC, USAID.

USAID (2005a) At Freedoms Frontiers: a democracy and governance strategic framework, Washington DC, USAID. Available from: http://www.usaid.gov/policy/0512_democracy_framework.pdf

Vandermoortele J, Malhorta K and Lim J. A. 2003) Is MDG 8 on Track as a Global Deal for Human Development? New York, UNDP.

Vandermoortele, J. (2004) Can the MDGs Foster a New Partnership for Pro-Poor Policies? New York, UNDP.

Whaites A (2002) Making PRSPs Work: can rhetoric and reality really coincide? In: Whaites, A. (ed.) Masters of their own development, California, World Vision.

Wilkin P (2002) 'Global Poverty and Orthodox Security', Third World Quarterly, 23, 633645.

Wilkinson R (2005) Introduction: Concepts and issues in global governance. In: Wilkinson R. (ed.) The Global Governance Reader, London, Routledge, pp. 1-22.

Williams D and Young . (1994) 'Governance, the World Bank and Liberal Theory', Political Studies, 42, 84-100.

Wolfensohn J. D (1999) A Proposal for a Comprehensive Development Framework (A Discussion Draft), New York, World Bank. Available from: www.worldbank.org/cdf/cdf-text.htm

Woods. (2005) 'The Shifting Politics of Foreign Aid', International Affairs, 81, 393-409.

World Bank (1998a) Assessing Aid: what works, what doesn't, and why, Oxford, Oxford University Press.

World Bank (2000) World Development Report 2000/2001: attacking poverty, Washington DC, World Bank and Oxford University Press.

World Bank (2004) World Development Report 2005: a better investment climate for everyone, Washington DC, World Bank. 
World Bank (2004b) Republic of Rwanda - Decentralization and Community Development Project, Washington DC, World Bank.

World Bank (2006) Project Appraisal Document on a Proposed Credit in the amount of SDR 14.8 Million (USs2 1.6 Million Equivalent) to the Republic of Azerbaijan for a Judicial Modernization Project, New York, The World Bank.

World Bank (2007) Low-Income Countries under Stress (LICUS), Washington DC, World Bank. Available from: http://go.worldbank.org/50JUJLAG90

Young T (1995) 'A Project to be Realised': global liberalism and contemporary Africa Millennium: Journal of International Studies, 24, 527-546.

\footnotetext{
i The global development policy discourse and corresponding development interventions which seek to link security and development concerns

ii Within this paper, as within the securitization of development literature, global governance refers to the strategic networks that bring together governments, international organisations, NGOs and private companies. Rather than understanding global governance as attempting to facilitate order in the complexities of modern life (Rosenau, 2002:70), a critical approach to global governance is taken. From a neo-Gramscian perspective this means understanding global governance in the context of transformations in global capitalism and ongoing conflicts, whilst for post-structuralists, global governance broadly involves the "development of often insidious new ways of defining, invigilating, managing and indeed governing social relations" (Selby, 2003:8). Both critical approaches are discussed within this paper.
}

iii Annika Soder, Swedish State Secretary for Development, interview with author, December 2005

ivAnnika Soder, Swedish State Secretary for Development, interview with author, December, 2005.

v This discussion is concerned with neo-liberalism as governmentality, which Larner (2006) distinguished from neo-liberalism as policy and ideology. 